\title{
Assessment of Teachers' Attitude, Students' Attitude and Performance in Mathematics in Secondary Schools: A Case Study in Hawassa City and Hawassa Zuria Woredas, Ethiopia
}

\author{
Tesfaye Getahun Agdie ${ }^{1}$, Mamo Teketel Mekasha ${ }^{1}$, Anteneh Bezabih Ali ${ }^{2}$, Mekonnen Mamo ${ }^{1}$, \\ Muluken Mitiku' ${ }^{1}$, Sileshi Gone ${ }^{1}$ \\ ${ }^{1}$ Department of Mathematics, Hawassa University, Hawssa, Ethiopia \\ ${ }^{2}$ Department of Statistics, Hawassa University, Hawassa, Ethiopia
}

Email address:

tesfayeget2006@gmail.com (T. G. Agdie)

\section{To cite this article:}

Tesfaye Getahun Agdie, Mamo Teketel Mekasha, Anteneh Bezabih Ali, Mekonnen Mamo, Muluken Mitiku, Sileshi Gone. Assessment of Teachers' Attitude, Students' Attitude and Performance in Mathematics in Secondary Schools: A Case Study in Hawassa City and Hawassa Zuria Woredas, Ethiopia. American Journal of Theoretical and Applied Statistics. Vol. 8, No. 3, 2019, pp. 94-107.

doi: $10.11648 /$ j.ajtas.20190803.12

Received: May 11, 2019; Accepted: June 28, 2019; Published: July 31, 2019

\begin{abstract}
Mathematics is a tool in which students and youngsters get knowledge and experience about life, they learn how to deal with problems, apply their knowledge into real life problems, improve their ability on logical thinking and reasoning, and getting ready for their future life. The aim of this study was to assess the attitude of students towards Mathematics and to determine factors that affect students' performance in Mathematics. Primary data was collected from students and their teachers using self-administered questionnaire. Multiple linear regression analysis, One-Way ANOVA, and t-test were used to analyze the data. Out of 347 students participated in this study, 313 students belong to the Tabor Secondary School and Boricha Secondary School, government schools. The rest 34 students belong to Saint Daniel Comboni Secondary School, which is a private school. About $68 \%$ of the respondents did not agree on the existence of Mathematics club that's dedicated to maximizing Mathematics excellencies other than usual course schedule in their school. Most teachers disagreed on students' effort to find out the reasons for their mistakes while they solve mathematical problems instead they simply accepted their mistakes. Results also showed that scores of students at Comboni (private school) were higher than score of students at Tabor and Boricha schools (government schools). Male students had better Mathematics scores than female students in these schools. Students who were interested in Mathematics course had a better score than those students who were not interested. Sex of students, students' laziness to attend Mathematics related courses, students believe that Mathematics is an easy subject, students score in grade 10 national exam, student interest to solve Mathematics' problems with their classmates, the time that the student spent per week to study Mathematics, and their communication with their Mathematics teacher were the significant factors that determine the performance of the student in Mathematics. The researchers recommended that all concerned bodies have to do a lot in order to improve performance of students since Mathematics is a key subject for science and technology.
\end{abstract}

Keywords: Students, Mathematics, Performance, Teachers, Linear Regression Model

\section{Introduction}

Mathematics can be considered as one of the basic subjects for better understanding of sciences and technology. Especially, now days, the importance and role of mathematics in the development of science and engineering are unquestionable. Countries are also recognizing that quality educations in the sciences, particularly in mathematics determine their future courses in science and technology advancements. However, many Mathematicians in the world have often expressed their grief that the majority of their students do not understand mathematical concepts, or 
does not see why mathematical procedures work, or does not know when to use a given mathematical technique [1].

Mathematics is considered by many individuals as a difficult subject to learn [2]. This kind of outlook has a direct impact with the achievement of students. It is clear that there are a number of factors that do influence students' mathematics achievement positively or negatively. But, the one among these factors that contribute more to the variations in mathematics achievement is the students' attitude towards mathematics.

There are various definitions of attitudes towards Mathematics by different scholars such as [1, 3-9, 11, 15], list some of them. For instance, Ma, X. [9] defined attitude as "an aggregate measure of a liking or disliking of Mathematics, a tendency to engage in or avoid mathematical activities, a belief that one is good or bad at Mathematics, and a belief that Mathematics is useful or useless". The emergence of negative attitudes is a result of frequent failures or interruptions of planned actions, which were intended to face mathematical tasks. Repeated emotional reactions result in the formation of an overall schema about Mathematics, which becomes relatively permanent [10]. A number of researches have so far indicated that many children begin schooling with positive attitude towards Mathematics. However, these attitudes tend to become less positive as children grow up, and frequently become negative at the high school $[2,9]$ refers to the attitude as a learned predisposition or tendency of an individual to respond positively or negatively to some object or situation, concept or another person. This positive or negative feeling is of moderate intensity and reasonable stability; sometimes it is especially resistant to change.

For instance, Aiken [3] pointed out that student with negative attitudes towards mathematics would perform less in mathematics because they develop anxiety. Many students develop anxiety towards mathematics due to a failure during previous grades. Hence, the effort must made to resolve this fear before preceding to the next grade as students learn new mathematical concepts and procedures by building on what they already know. Learning with understanding can be viewed as making connections or establishing relationships either with the existing knowledge, or between existing knowledge and new information. If students have a positive attitude towards mathematics, it is likely that they will allot a considerable portion of their study time to the subject and strive to master the necessary knowledge's and skills.

The study had made the University of Evora, Portugal; aims to determine the attitude of freshmen students who were taking a mathematics subject in the fall semester of the academic year 2013 to 2014 at the University of Evora [8]. The study was based on data collected using a questionnaire about students' attitude towards mathematics and their motivation, interest, perceived competence, and anxiety levels. The results of their study revealed that freshman students generally have a positive attitude towards mathematics prior to commencing University formation. Meaning that, there is a strong positive correlation between attitude and motivation and interest, perceived competence and anxiety dimensions.

Various studies focused on investigating student's attitudes towards mathematics, self-efficacy and achievement in problem solving $[12,13]$. The study aimed to explore the relationship between students' attitudes towards mathematics, self-efficacy beliefs in problems solving and achievement. The possibility of attitudes and self-efficacy to predict problem solving performance was also examined. Attitudes and efficacy scales were completed by 238 fifth-grade pupils. Problem-solving performance was measured by a specially prepared test, including simple and multi-step problems. The study result revealed that there is a significant relationship between attitudes and achievement, and a stronger relationship between efficacy and achievement. Attitudes and efficacy were also correlated and both predicted achievement in problem-solving. However, efficacy was a more powerful predictor than attitudes. No gender difference was found in any of the examined variables.

Some studies had targeted on students' attitude towards mathematics and their performance from the perspectives of teacher's attitudes [12]. Meaning that, the study was fashioned to extend the influence of teacher attitude on student attitude towards Mathematics and their performance. The study considered a sample of one hundred students (selected randomly) and for Mathematics teachers (selected purposively) making a total of one hundred and four respondents. Questionnaires and students' end of term examination scores were used as a measure of students' academic achievements. The study revealed a significant relationship between teacher attitude and student attitude toward Mathematics. The results of the study were also consistent with existing findings on the relationship between teacher attitude and students; performance in Mathematics.

Investigated Teachers' and Students' attitude towards Mathematics in secondary schools in Siaya County, Kenya [14]. The study aimed to find out the relationship among teachers' attitude and students' performance in Mathematics in Kenya certificate of secondary education (KCSE). The study is an ex-post facto type, which adopted descriptive survey design. The subjects for the study were one hundred and seventy-one (171) students and twenty-three (23) mathematics teachers selected from secondary schools in Siaya County, Kenya. The collected data were analyzed using simple frequency and percentages. The findings revealed that there was a good and positive attitude of teachers towards the teaching of mathematics in secondary schools in spite of the shortcomings that has bedeviled the teaching profession and particularly in the teaching of Mathematics. It is very important that teachers of Mathematics should be motivated, well equipped and be psychologically prepared to teach the subject in the secondary schools.

In fact, we are aware of as different concerned organizations try to find the potential determinants and working hard to attract and maximize the performance of students in Mathematics. Still the new generation's attitude towards Mathematics discipline is under question. Similarly, the implementation of different Mathematics courses in 
science and technology institutions has also many problems as mentioned by both students and teachers. In addition to this, from our informal observations, most students who took the Mathematics exam didn't get a passing grade and also the Mathematics department is not a students' first choice. This happens due to many factors. Factors /contributing to students' performance in Mathematics needs to be determined. Since there is no intensive research made on students' attitude, interest, and performance locally; we planned to address the following research questions:

i. What are the determining factors that affect students' performance?

ii. What does the level of high school students' attitude towards Mathematics and Mathematics teachers looks like?

iii. Is there any significant difference between male and female students in performance of Mathematics?

iv. How much the students understand the importance of the subject?

The general objective of this research is to find the determinant factors that affect students' performance in Mathematics. Specifically authors concerned on:

i. To identify the effects of students' sex, family background, and occupation on their Mathematics performance.

ii. To determine the effect of students' study time on their Mathematics performance

iii. To explore the students' attitude and interest in Mathematics and its effect on their academic performance.

iv. To identify the score difference between students who attended their high school education in Comboni school (private school) and Tabor and Boricha schools (government schools)

v. To assess teachers' response on teaching methodologies, physical facilities, and students attitude towards learning Mathematics.

\section{Materials and Methods}

\subsection{Description of the Study Area}

Hawassa is the capital city of Southern Nation, Nationality and Peoples Regional State. It is located in Sidama zone 270 $\mathrm{km}$ south of Addis Ababa, $130 \mathrm{~km}$ east of Welayta Soddo and $90 \mathrm{~km}$ north of Dilla. This town is well known by Lake Hawassa. It makes the town more beautiful in Ethiopia. The subjects of this study are students who were learning at Hawassa and Hawassa Zuria at Comboni High School (private school), and Tabor and Boricha High Schools (government schools) at the time of study. Teachers in the same schools were also considered as the subjects of this study.

\subsection{Target Population}

All high school students found in Hawassa and Hawassa Zuria were considered as the study population. Mainly, the study focused on students who were attending in Comboni, Tabor and Boricha high schools during the study time. There were about 1347 grade12 students who attended their high school education in the above schools. From these, we took an appropriate sample of 347.

\subsection{Study Design}

In this study, cross-sectional data are used since the data were collected at one point in the time.

\subsection{Method of Data Collection}

In this study, relevant primary data was collected from students and teachers who were included in the study using self-administered questionnaire. Questionnaires were translated from the English language to the Amharic language to be able to understand by the students and teachers easily. Prior to data collection, orientation was given to all Mathematics teachers and in order to randomly selected students in the three schools on how to fill the questionnaire. Then, the questionnaires were distributed to each respondent and collected by the researcher after they filled them. These were made deliberately by the researcher in order to improve the quality of the data.

\subsection{Sampling Techniques and Sample Size Determination}

To get a representative sample, the researcher used stratified random sampling techniques by considering each school as stratum and by assuming students in different school have different characteristics. The sample was then taken in each stratum by applying the proportional allocation to size. The sample size is determined as follows

$$
n_{0}=\frac{\sum W_{h} s_{h}^{2}}{V}
$$

where, $V=\frac{d^{2}}{z_{\alpha / 2}^{2}}=\frac{(1.11)^{2}}{(1.96)^{2}}=0.321$

$$
=\frac{(1056 / 1357)(162)+(159 / 1357)(102)+(132 / 1357)(114)}{0.321}
$$$$
=467.94 \approx 468
$$

$$
n=\frac{n_{0}}{1+n_{0} / N}=\frac{468}{1+468 / 1357}=347.3 \approx 347
$$

Using proportional allocation, the sample size for each stratum, $n_{h}$ was calculated as follow:

$$
\begin{gathered}
N_{1}=1056 N_{2}=159, N_{3}=132, n_{h}=\frac{N_{h}}{N} * n \\
n_{1}=\frac{N 1 * n}{N}=\frac{1056}{1347} * 347=272.04=272 \\
n_{2}=\frac{N 2 * n}{N}=\frac{159}{1347} * 347=40.96=41 \\
n_{3}=\frac{N 3}{N} * n=\frac{132}{1347} * 347=34
\end{gathered}
$$


where,

$Z \alpha / 2=$ Critical Value of standard normal variable, usually

1.96 is taken for $5 \%$ level of significance.

$S_{i}^{2}=$ Sample variance taken from pilot survey i.e.

$$
S_{1}^{2}=162, S_{2}^{2}=102, S_{3}^{2}=114
$$

$\mathrm{d}=$ degree of accuracy desired, $d=1.11$

$\mathrm{n}=$ Over all sample size, $n=347$.

$\mathrm{N}_{1}=$ Total number of students in Tabor High School.

$\mathrm{n}_{1}=$ Sample of students in the Tabor High School.

$\mathrm{N}_{2}=$ Total number of students Boricha High School

$\mathrm{n}_{2}=$ Sample of students in Boricha High School.

$\mathrm{N}_{3}=$ Total number of students in Comboni High School

$\mathrm{n}_{3}=$ Sample of students in Comboni High School

$\mathrm{N}=$ population size

\subsection{Variables included in the Study}

\subsubsection{Dependent Variable}

Students' Mathematics scores on the grade 11 Mathematics course.

\subsubsection{Independent Variable}

i. Age

ii. Sex

iii. Father Education

iv. Father Occupation

v. Mother Education

vi. Mother Occupation

vii. Students Grade 10 National Exam

viii. Students Attitude towards Mathematics and the teaching methodology

ix. Students' interest in Mathematics

x. Students Study Time for Mathematics Course

xi. Students cooperation with their classmate to do Mathematics problems

\subsection{Method of Data Analysis}

The collected data were entered into SPSS software and analyzed using descriptive statistics, t-test, ANOVA, and regression analysis.

\subsubsection{Multiple Linear Regression Model}

The multiple linear regression model for a response variable, Y, with observed values, $y_{1}, y_{2}, \ldots, y_{n}$ i.e. Students' Mathematics score, where $n$ is the sample size and $p$ explanatory variables, $X_{1}, X_{2}, \ldots, X_{p}$ with observed values, $x_{1 i}, x_{2 i} \ldots, x_{p i}, i=1, \ldots, n$, is given as:

$$
Y_{i}=\beta_{0}+\beta_{1} X_{1 i}+\beta_{2} X_{2 i}+\ldots+\beta_{p} X_{p i}+\varepsilon_{i}
$$

where, $\beta_{0}$ is intercept

$\beta_{1}, \ldots, \beta_{p}$ are slope or coefficient for a given independent variable

$\varepsilon_{i}$ is the error term for individual $i$.

Hypothesis Testing for the Overall Significance of Regression Model (ANOVA):

$H_{0}: \beta_{1}=\cdots=\beta_{p}=0$, all of the independent variables are not important or their effect is not significant.

$H_{1}$ : at least on $\beta_{i} \neq 0$, there is at least one independent variable that can determine the variance of the dependent variable.

Test Statistics:

$$
\mathrm{F}_{\text {Cal }}=\frac{(\text { Regression Mean Square })}{(\text { Residual Mean Square })}=\frac{\mathrm{SSR} / \mathrm{K}}{\mathrm{SSE} /(\mathrm{n}-\mathrm{k}-1)}
$$

where:

Regression Sum of Squares (SSR) $=\hat{\beta}^{\prime} X^{\prime} Y$

Error Sum of Squares (SSE) $=Y^{\prime} Y-\hat{\beta}^{\prime} X^{\prime} Y$

Decision Rule: If the computed F-value is higher than the tabulated F-value with $\mathrm{p}-1$ degree of freedom for regression (numerator degree of freedom) and n-k-1 degree of freedom for Residual (denominator degree of freedom) at $\alpha=0.05$ significance level, then we reject $\mathrm{H}_{0}$.

\subsubsection{Parameter Estimation of the Regression Model}

To estimate the parameters, the researcher used least squares estimation technique. The least squares estimate of a vector of linear regression coefficients $\beta$ is given by:

$$
\hat{\beta}=\left(X^{\prime} X\right)^{-1} X^{\prime} y
$$

\subsubsection{Assessments of the Model Fit}

A measure of the goodness of fit of the model is provided by the Coefficient of Determination, $\mathrm{R}$, defined as the explained variation of the response variable.

The value of $R^{2}$ gives the proportion of the variability of the response variable accounted for by the explanatory variables. $\mathrm{R}$ ranges in value from 0 to 1 and when $\mathrm{R}$ approaches to 0 , the estimated regression equation explains none of the variation in $\mathrm{Y}$ and when it approaches to 1 that means all points lie on the regression line and the estimated regression equation explains well. Coefficient of determination (adjusted $\mathrm{R}^{2}$ ) was used to interpret the variability. The individual regression coefficient was assessed using t-test statistic given as the ratio of the coefficient to standard error of each coefficient. To diagnostic for normality, the researcher used Q-Q plot and histogram. To check the Multicollinearity, the researcher used Variance Inflation Factor (VIF).

Assumption of Multiple Linear Regression Model

1. The explanatory variables are assumed to be fixed; that is, they are not considered random variables.

2. The dependent variable is a linear function of the predictor variables.

3. The residuals are assumed to be independent and normally distributed. with mean zero and variance $\sigma^{2}$.

4. There is no serious Multicollinearity problem.

\subsubsection{Independent T-tests}

In this study comparison of two groups is made using independent sample t-test. The hypothesis of testing the difference of $\mu_{1}$ and $\mu_{2}\left(\mu_{1}-\mu_{2}\right)$ was made as:

$H_{0}: \mu_{1}-\mu_{2}=0$, there no mean difference between the two groups

$H_{1}$ : There is mean difference between the two groups 


\section{Results and Discussions}

For this study 347 Students and 37 teachers were taken. This chapter is divided into different sections. In the first section, the researcher checked the reliability of the data. The second section deals with demographic characteristics, school and family background of students, information related to teaching and learning of Mathematics and students' interest/attitude towards Mathematics. In the third section, the researcher discussed about general background information about teachers, teacher's response to the physical facility in the school, the teacher's response on teaching methodological aspects, and the teacher's response on the attitudes of students toward learning Mathematics. The fourth section deals with chi-square association between students' background and their grade, 10th Mathematics Score, independent sample t-test for students' Mathematics score in grade 11th, ANOVA, and multiple comparisons. Finally, in the fifth section, the researcher tried to identify factors related to students' performance (grade 11 score) using multiple linear regression analysis.

\subsection{Reliability Assessment}

The statistical analysis of reliability assessment of the school facility, interest of students and students' perception towards teachers was indicated in Table 1 below.

Table 1. Reliability statistics for total items.

\begin{tabular}{ll}
\hline Cronbach's Alpha & N of Items \\
\hline .738 & 53 \\
\hline
\end{tabular}

Source: Own survey (2017)

Using Cronbach coefficient alpha, internal consistency of the overall questionnaire was estimated to be 0.738 . The high coefficient of Cronbach's alpha shows that the higher the internal consistency of the questionnaire, the most reliable results of assessment is. Usually a reliability coefficient above 0.70 is considered sufficient for exploratory studies. The reliability value in this case is above 0.70 , hence it can be concluded that the measures used in this study are reliable.

\subsection{Results of Descriptive Statistics of Students}

Table 2 below shows the demographic background of the students. Out of 347 students participated in this study, 313 students belong to the Tabor Secondary School and Boricha Secondary School (government schools) and the rest 34 students belong to Saint Daniel Comboni Secondary School (private school). The mean Mathematics' score of students in grade 11 was 66.72 with a standard deviation of 12.76 for Tabor, 64.71 with a standard deviation of 10.14 for Boricha, and 73.32 with a standard deviation of 10.72 for Saint Daniel Comboni.

Among total students participated in this study, 51.3\% of them are male and $48.7 \%$ of them are females. On average, male students scored 70.39 with a standard deviation of 12.75 and females scored 63.69 with a standard deviation of 11.17 in grade 11 Mathematics course in the 2007 academic year.

Considering students' fathers' educational level, 45 of them were non-educated, 90 of them completed the first cycle (18), 62 of them completed high school, and the remaining 150 (43.2\%) completed college diploma and above. From the given data, it is also possible to observe that the mean score of students whose fathers completed a college diploma or above were 69.43. Similarly, when we consider students' mothers' educational level, 44 of them were non-educated, 138 of them were first cycle completed, 80 of them were high school completed and the remaining 85 of them were college and above completed. The mean Mathematics score in grade 11 was 69.24 for those students whose mothers have a college diploma and above.

Information about occupation of the respondents' fathers and mothers are also important to know about the attitude and achievement of students towards the Mathematics subject. As indicated in Table 2, the majority of the respondents' fathers, $95 \quad(27.4 \%)$ were government employees (different from teaching), 78 (22.5\%) were NGO employees, $25(7.2 \%)$ of them were teachers, 71 (20.5) of them were farmers, and the rest $78(22.5 \%)$ were merchants. The mean Mathematics score in grade 11 for those students whose fathers were government employees and teachers were 71.55 and 69.88 respectively. When we look at the occupation of the students' mothers, 159 were house wife, 80 of them were merchants, 18 of them were farmers, 17 of them were teachers, 26 of them were NGO employees, and 47 of them were government employees (different from teaching). Association with students score, the maximum mean score, which was about 73.53 was achieved by students whose mother were teachers.

Table 2. General background information of students.

\begin{tabular}{|c|c|c|c|c|}
\hline \multirow{2}{*}{ Variables } & \multirow{2}{*}{ Category } & \multirow{2}{*}{ Frequency } & \multicolumn{2}{|c|}{ Grade $11^{\text {th }}$} \\
\hline & & & Mean & SD \\
\hline \multirow{2}{*}{ Sex of respondents } & Male & $178(51.3)$ & 70.39 & 12.75 \\
\hline & Female & $169(48.7)$ & 63.69 & 11.17 \\
\hline \multirow{3}{*}{ Name of Schools } & Tabor S/S & $272(78.4)$ & 66.72 & 12.76 \\
\hline & Boricha S/S & $41(11.8)$ & 64.71 & 10.14 \\
\hline & Comboni S/S & $34(9.8)$ & 73.32 & 10.72 \\
\hline \multirow{4}{*}{ Father Educational Level } & Non-educated & $45(13)$ & 65.72 & 12.61 \\
\hline & First cycle completed (1-8) & $90(25.9)$ & 63.79 & 11.55 \\
\hline & High school completed & $62(17.9)$ & 67.40 & 11.31 \\
\hline & College and above & $150(43.2)$ & 69.43 & 12.97 \\
\hline Mother Educational Level & Non-educated & $44(12.7)$ & 64.69 & 12.81 \\
\hline
\end{tabular}




\begin{tabular}{|c|c|c|c|c|}
\hline \multirow{2}{*}{ Variables } & \multirow{2}{*}{ Category } & \multirow{2}{*}{ Frequency } & \multicolumn{2}{|c|}{ Grade $11^{\text {th }}$} \\
\hline & & & Mean & SD \\
\hline \multirow{7}{*}{ Father Occupation } & First cycle completed (1-8) & $138(39.8)$ & 66.05 & 12.06 \\
\hline & High school completed & $80(23.1)$ & 68.06 & 12.08 \\
\hline & College and above & $85(24.5)$ & 69.24 & 13.03 \\
\hline & Merchant & $78(22.5)$ & 65.71 & 10.65 \\
\hline & Farmer & $71(20.5)$ & 63.75 & 13.31 \\
\hline & Teacher & $25(7.2)$ & 69.88 & 11.90 \\
\hline & NGO & $78(22.5)$ & 65.35 & 12.66 \\
\hline & $\begin{array}{l}\text { Government employee other than } \\
\text { teacher }\end{array}$ & $95(27.4)$ & 71.55 & 11.99 \\
\hline \multirow{6}{*}{ Mother Occupation } & Housewife & $159(45.8)$ & 66.10 & 12.86 \\
\hline & Merchant & $80(23.1)$ & 67.05 & 10.56 \\
\hline & Farmer & $18(5.2)$ & 64.17 & 12.68 \\
\hline & Teacher & $17(4.9)$ & 73.53 & 10.22 \\
\hline & NGO & $26(7.5)$ & 69.65 & 11.78 \\
\hline & $\begin{array}{l}\text { Government employee different from } \\
\text { Teacher }\end{array}$ & $47(13.5)$ & 68.17 & 14.43 \\
\hline \multirow{3}{*}{ Number of classes attended/ week } & Attend all 5 classes & 274(78.96) & 68.37 & 12.85 \\
\hline & Attend 3 or 4 classes & $57(15.24)$ & 62.77 & 8.69 \\
\hline & Attend at most 2 classes & $16(4.6)$ & 61.44 & 12.40 \\
\hline
\end{tabular}

Table 2 demonstrates the student's response to the questions linked to teaching and learning in the school. According to the information in the table, $68 \%$ of the respondents did not agree on the existence of the Mathematics club in their school, which is dedicated to maximize Mathematics Excellencies other than the usual course schedule whereas only $19.6 \%$ of them agreed on it. Among the $19.6 \%$ who agreed on the existence of the Mathematics club, $73.5 \%$ admitted the supports of the club to discuss with each other in their free period of time while the rest $10.3 \%$ did not admit the situation.

According to the students' response, $59.7 \%$ of them agreed that they have a Mathematics text book so that they didn't have any problem in this regard and $10.1 \%$ were neutral in this view. Besides this, $53.6 \%$ of the respondents believed that in addition to the standard textbook other Mathematics reference books were supportive to easily understand the subject matter, whereas $28.8 \%$ of them did not agree on the existence of sufficient Mathematics reference books in the school library and $11.8 \%$ were neutral on this concern.

About $44.1 \%$ of the respondents did not agree on the existence of pedagogical center in their school where as only $36.6 \%$ of them agreed on it. This in mind, out of the respondents who agreed on the existence of pedagogical center in their school, $52.8 \%$ of them agreed on the supports of their visit to understand the subject in a better way and $30.7 \%$ disagreed with it. In addition to this, $60.4 \%$ agreed on the supports of the participation in the center to understand the pedagogical tools in a better way but $27.5 \%$ disagreed with it.

Concerning the availability of Mathematics teachers outside the classroom and their supports to understand the subject in a better way, $36.6 \%$ disagreed and $51.3 \%$ of them agreed on it.

Table 3. Students' attitude related to teaching and learning of Mathematics.

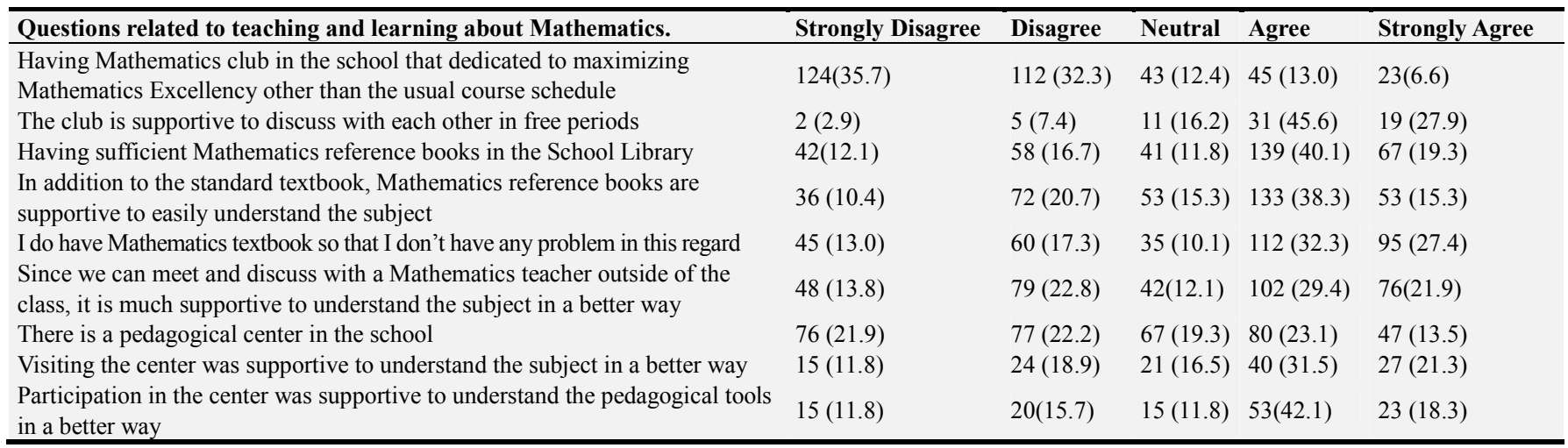

With all this condition in the school environment, the following table displayed the students' interest towards the Mathematics subject (See Table 4).

As the result demonstrated in Table 4, the response of the students for the question related to the student's attitude towards the Mathematics subject indicated that, $53.3 \%$ of the respondents disagreed with using Mathematics to solve problems challenging from the real world while only $33.8 \%$ agreed on it. Most of the respondents (65.4\%) think that Mathematics is the subject that can motivate innovative and very relevant to human beings while only few (24.2\%) of them did not think.

Since people learn better when they have an interest in the subject matter, the necessity of interest in learning does not 
only means that someone has an interest in learning about something. It also means that when someone has an interest in something it becomes easy and even enjoyable to learn about that topic. It is natural for people to saturate up all sorts of information when they have an interest in learning about that particular subject. As indicated in Table 4, 31.1\% of the respondents did not have an interest in Mathematics and $56.8 \%$ had an interest in Mathematics. In addition to this, $62.5 \%$ did not consider Mathematics as too difficult while $23.9 \%$ consider it as it is too difficult subject. Having this in mind, $44.4 \%$ of the respondents did not take Mathematics as an easy subject for them while $40.4 \%$ of them took it as an easy subject for them. Besides this, $69.8 \%$ did not consider themselves as lazy in Mathematics and then they were not happy while attending Mathematics related subjects, but $21.0 \%$ of them consider themselves as lazy in Mathematics. According to the result indicated in Table 4, 73.2\% of the respondents did not believe that Mathematics is for naturally gifted students so that others are unable to be clever in the subject but only $16.1 \%$ of the respondents believed that Mathematics is for naturally gifted students. In line with this, $73.7 \%$ disagreed with the idea that Mathematics is much easier for males than females but $15.8 \%$ agreed on it. About $22.7 \%$ agreed with the opinion that Mathematics has been relevant just to pass the exam only where as $65.4 \%$ disagreed with it. $57.1 \%$ agreed that when they attend Mathematics, they can easily understand current events and reports and $27.7 \%$ did not agree on this.

In relation to students' attitude towards studying Mathematics; as indicated in the Table 4, 64.3\% preferred not to study Mathematics while they are thinking Mathematics is a collection of formula and theorems so that difficult to grasp the concept while only $28 \%$ prepared to study it. About $53 \%$ of the students were not taking longer time to study Mathematics and thus they preferred to study just after they completed other subjects but $33.1 \%$ of them contradicted to this idea. Besides this, $49.3 \%$ were happy while they solve problems related with Mathematics but $36.6 \%$ were not. About $45.5 \%$ had less confidence to solve Mathematics problem and $35.7 \%$ did not have. About $61.4 \%$ always checked the solution by substituting on the original problem after solving the problem, but $13.1 \%$ did not do it. About $47.9 \%$ agreed that after solving Mathematics question, they always find out the alternative way while $38.4 \%$ disagreed with it.

Even though most of the respondents preferred not to study Mathematics while they are thinking Mathematics is a collection of formula and theorems so that difficult to grasp the concept, once they start studying the subject $67.7 \%$ struggle many times to have the correct solution while they made wrong solution whereas only $23.1 \%$ have no tendency to struggle. In addition to this, $64.6 \%$ of them always tried all the best to understand those questions solved by their classmates and 33.1 did not try to do so.

Besides this, Table 4, disclose that, $66.3 \%$ agreed that they can learn Mathematics playing with different things but $21.6 \%$ did not agree with it. In addition to this $56.2 \%$ agreed that if Mathematics teaching is supported by computer, it is better to understand more but $23.0 \%$ did not agree. However, $51.6 \%$ of the students didn't utilize Mathematics software, whereas $27.1 \%$ of them utilized Mathematics software and thus it supported them to easily understand the subject.

Finally, Table 4, reveals that, $35.8 \%$ of the respondents agreed that friend's bad feeling towards Mathematics has its own impact but $50.1 \%$ disagreed with this idea.

Table 4. Students interest/attitude towards Mathematics subject.

\begin{tabular}{|c|c|c|c|c|c|}
\hline Students' interest/attitude towards the Mathematics subject & SD & DA & $\mathbf{N}$ & A & SA \\
\hline I can use Mathematics to solve problems challenging in the real world & $65(18.7)$ & $120(34.6)$ & $45(13.0)$ & $79(22.8)$ & $38(11.0)$ \\
\hline Mathematics is only for nature gifted students so that others are unable to be clever in the subject & $137(39.5)$ & $117(33.7)$ & $37(10.7)$ & $33(9.5)$ & $23(6.6)$ \\
\hline Mathematics is much easier for Male than Female & $166(47.8)$ & $90(25.9)$ & $36(10.4)$ & $30(8.6)$ & $25(7.2)$ \\
\hline I tried many times to have the correct solution while I did wrong & $94(27.1)$ & $141(40.6)$ & $32(9.2)$ & $44(12.7)$ & $36(10.4)$ \\
\hline I prefer to study other subject while I am thinking, studying Mathematics is time taken & $108(31.1)$ & $95(27.4)$ & $33(9.5)$ & $72(20.7)$ & $39(11.2)$ \\
\hline $\begin{array}{l}\text { Prefer not study Mathematics while the student thinks Mathematics is a collection of } \\
\text { formula and Theorem }\end{array}$ & $121(34.9)$ & $103(29.7)$ & $41(11.8)$ & $44(12.7)$ & $36(10.4)$ \\
\hline The student is happy while he/she solves problems related to Mathematics & $54(15.6)$ & $73(21.0)$ & $49(14.1)$ & $102(29.4)$ & $69(19.9)$ \\
\hline I am trying all the best to understand those questions solved by my class colleagues & $42(12.1)$ & $55(15.9)$ & $27(7.8)$ & $139(40.1)$ & $84(24.2)$ \\
\hline For me, Mathematics is too difficult & $123(35.4)$ & $94(27.1)$ & $47(13.5)$ & $42(12.1)$ & $41(11.8)$ \\
\hline After solving Mathematics question, I always find out the alternative way & $53(15.3)$ & $80(23.1)$ & $48(13.8)$ & $114(32.9)$ & $52(15.0)$ \\
\hline $\begin{array}{l}\text { Since I am lazy in Mathematics and then I am not happy while attending Mathematics } \\
\text { related subject }\end{array}$ & $122(35.2)$ & $120(34.6)$ & $32(9.2)$ & $41(11.8)$ & $32(9.2)$ \\
\hline Mathematics is the subject that can motivate innovative and very relevant to human being & $49(14.1)$ & $35(10.1)$ & $36(10.4)$ & $102(29.4)$ & $125(36.0)$ \\
\hline Being I am attending Mathematics, I can easily understand current events and reports like... & $45(13.0)$ & $51(14.7)$ & $50(14.4)$ & $118(34.0)$ & $80(23.1)$ \\
\hline I have a good interest in Mathematics & $40(11.5)$ & $68(19.6)$ & $42(12.1)$ & $112(32.3)$ & $85(24.5)$ \\
\hline For me, Mathematics is the easiest subject & $63(18.2)$ & $91(26.2)$ & $52(15.0)$ & $97(28.0)$ & $43(12.4)$ \\
\hline In my opinion, Mathematics has been relevant just to pass an exam only & $124(35.7)$ & $103(29.7)$ & $41(11.8)$ & $47(13.5)$ & $32(9.2)$ \\
\hline Learn Mathematics playing with different things & $35(10.1)$ & $40(11.5)$ & $42(12.1)$ & $133(38.3)$ & $97(28.0)$ \\
\hline If teaching Mathematics is with the support of computer, it is better to understand more & $32(9.2)$ & $48(13.8)$ & $72(20.7)$ & $95(27.4)$ & $100(28.8)$ \\
\hline After solving the problem, I always check the solution by substituting on the original problem & $42(12.1)$ & $38(1.0)$ & $54(15.6)$ & $150(43.2)$ & $63(18.2)$ \\
\hline Has less confident to solve Mathematics Problem & $50(14.4)$ & $74(21.3)$ & $65(18.7)$ & $99(28.5)$ & $59(17.0$ \\
\hline $\begin{array}{l}\text { I have utilized Mathematics Software and thus, it is supported me to easily understand the } \\
\text { subject }\end{array}$ & $95(27.4)$ & $84(24.2)$ & $74(21.3)$ & $58(16.7)$ & $36(10.4)$ \\
\hline Students prefer to study Mathematics after other subjects since it takes longer time to study & $84(24.2)$ & $100(28.8)$ & $45(13.0)$ & $75(21.6)$ & $40(11.5)$ \\
\hline My friends bad feeling towards Mathematics has its own impact to myself & $82(23.6)$ & $92(26.5)$ & $46(13.3)$ & $63(18.2)$ & $61(17.6)$ \\
\hline
\end{tabular}


As indicated in Table 5, most of the respondents (84.7\%) agreed that someone who understands mathematics can easily understand other science and technology disciplines. $55 \%$ of the respondents had difficulty in solving Mathematics word problems and $42.4 \%$ had no habit to ask while they were unable to understand the concept during class discussion.

Table 5. Understanding Mathematics problems.

\begin{tabular}{lll}
\hline & Yes & No \\
\hline $\begin{array}{l}\text { Solving mathematics word problems is difficult } \\
\text { Asked someone to understand the concept of the }\end{array}$ & $191(55)$ & $156(45)$ \\
problem during class discussion & $191(55)$ & $147(42.4)$ \\
$\begin{array}{l}\text { Understanding mathematics is much supportive to } \\
\text { understand other science and technology subjects } \\
\text { easily }\end{array}$ & $294(84.7)$ & $47(13.5)$ \\
\hline
\end{tabular}

\subsection{Descriptive Statistics on Teachers' Responses}

\subsubsection{Demographic Characteristics'of Teachers}

Table 6 shows the results on 37 Mathematics teachers who teach in grades 9-12 at three different secondary and preparatory schools. 25 of them were from Tabor, 8 of them were from Boricha and 4 of them were from Comboni secondary and preparatory schools.

Out of 37 respondents, $81.1 \%$ (30) of them were male and $18.9 \%$ (7) of them were female teachers. These teachers have different educational level and service years. About 13.5\% of the teachers were diploma holders, $81.1 \%$ of them were $\mathrm{BED} / \mathrm{BSC}$ holders, and $5.4 \%$ of them were MSc holders in Mathematics subject. About $64.9 \%$ of the teachers have less than 15 hours average load per week and the remaining (35.1\%) have 16-20 hours average load per week. Moreover, almost all $(81.1 \%)$ of the teachers have more than 6 years' experience in teaching Mathematics

Table 6. General background information of teachers.

\begin{tabular}{|c|c|c|c|}
\hline Variables & Category & Frequency & Percent \\
\hline \multirow{3}{*}{ Name of Schools } & Tabor & 25 & 67.6 \\
\hline & Boricha & 8 & 21.6 \\
\hline & Comboni & 4 & 10.8 \\
\hline \multirow{2}{*}{ Sex of respondents } & Male & 30 & 81.1 \\
\hline & Female & 7 & 18.9 \\
\hline \multirow{3}{*}{ Age of respondents } & Less than 26 & 3 & 8.1 \\
\hline & $26-35$ & 23 & 62.2 \\
\hline & More than 45 & 4 & 10.8 \\
\hline \multirow{4}{*}{ Educational Qualification for Teachers } & Diploma in Mathematics & 5 & 13.5 \\
\hline & $\mathrm{BEd} / \mathrm{BSc}$ in Mathematics & 30 & 81.1 \\
\hline & MSc in Mathematics & 2 & 5.4 \\
\hline & $<=6.0$ & 7 & 18.9 \\
\hline \multirow{3}{*}{ Service year as a Mathematics teacher } & $7.0-12.0$ & 19 & 51.4 \\
\hline & $13.0-18.0$ & 3 & 8.1 \\
\hline & $31.0+$ & 1 & 2.7 \\
\hline \multirow{2}{*}{ An average load of teachers per week } & Less than $15 \mathrm{Hrs}$ & 24 & 64.9 \\
\hline & $16-20 \mathrm{Hrs}$ & 13 & 35.1 \\
\hline
\end{tabular}

\subsubsection{Teacher's Responses on Physical Facility in the School}

As indicated in Table 7, 56.7\% of the respondents agreed that there is no free room for students to share their experience outside the classroom. However, more than $70 \%$ of the teachers agreed that there are sufficient Mathematics reference books in the school library. Hence, most of the teachers agreed that there is no room outside of the class that is used for giving advice to the students.

Even though there is difference in school facility among the schools, most of the respondents agreed on the idea that there is no sufficient computer access for both students and teachers to support students and so that students can improve their Mathematics knowledge by applying different software packages. In addition, there is no pedagogical center in which students can practice their theoretical skill into practice. In general, the teacher responses indicated that there were lacks of additional support to facilitate the teaching learning process in the schools.

Table 7. Teachers' response on physical facility in the school.

\begin{tabular}{|c|c|c|c|c|c|c|}
\hline No. & Questions related to Physical facilities in the school & $\begin{array}{l}\text { Strongly } \\
\text { Disagree }\end{array}$ & Disagree & Neutral & Agree & $\begin{array}{l}\text { Strongly } \\
\text { Agree }\end{array}$ \\
\hline 1 & $\begin{array}{l}\text { In our school, there is a room/free class in which students share their experience in } \\
\text { Mathematics to develop their creativity and abilities in Mathematics out of the classroom. }\end{array}$ & $11(29.7)$ & $10(27.0)$ & $8(21.6)$ & $7(18.9)$ & $1(2.7)$ \\
\hline 2 & $\begin{array}{l}\text { In our school, there is a library in which sufficient Mathematics references which helps } \\
\text { students to understand Mathematics in a better way }\end{array}$ & $2(5.4)$ & $5(13.5)$ & $4(10.8)$ & $14(37.8)$ & $12(32.4)$ \\
\hline 3 & In our school Mathematics teachers have rooms that are used to help and advise students & $7(18.9)$ & $8(21.6)$ & $10(27)$ & $11(29.7)$ & $1(2.7)$ \\
\hline
\end{tabular}




\begin{tabular}{|c|c|c|c|c|c|c|}
\hline No. & Questions related to Physical facilities in the school & $\begin{array}{l}\text { Strongly } \\
\text { Disagree }\end{array}$ & Disagree & Neutral & Agree & $\begin{array}{l}\text { Strongly } \\
\text { Agree }\end{array}$ \\
\hline & outside classrooms & & & & & \\
\hline 4 & $\begin{array}{l}\text { There is sufficient computer access for both students and teachers in the school which help } \\
\text { to introduce technology for students }\end{array}$ & $7(18.9)$ & $10(27)$ & $10(27)$ & $8(21.6)$ & $2(5.4)$ \\
\hline 5 & $\begin{array}{l}\text { At the school, there is a pedagogical center in which students can practice their skills by } \\
\text { constructing teaching/ learning models on Algebra, Geometry and other Mathematics } \\
\text { concepts of their own. }\end{array}$ & $5(13.5)$ & $11(29.7)$ & $10(27)$ & 11(29.7) & 0 \\
\hline 6 & Our school gives additional support for teaching learning process of Mathematics. & $6(16.2)$ & $11(29.7)$ & $7(18.9)$ & $11(29.7)$ & $2(5.4)$ \\
\hline
\end{tabular}

\subsubsection{Teacher's Response on Teaching Methodological Aspects}

Most teachers agreed that they make the classroom more participatory when they teach a lesson in Mathematics and they try to make the subject easier by using different techniques of solving problems. They also agreed that they include the historic evidences or development of mathematical facts that helped students to inspire and interested in Mathematics and they usually use teaching models (like geometric models) and graph to make the subject clear, interesting, realistic, and unforgettable.

In addition, most of the teachers agreed as they advise their students to study Mathematics for better understanding and internalize it for real world application. Most teachers agreed that doing Mathematics frequently is very important and they usually advise their students about this idea.
Teachers agreed that they tell their students about the role, application, and importance of Mathematics in day to day activities and in every field of study. They also agreed that they are working very hard on students to develop their psychological readiness and make them ready to learn Mathematics. Most of the teachers agreed that Mathematics software's helps students to learn Mathematics easily, but some of them have a gap on computer skill/knowledge. Only 9 teachers agreed that they try to link their computer skill/knowledge of the applications of Mathematics because of the above reasons. Most of the respondents agreed that they modify their teaching approach if they feel that majority of students are dissatisfied while they teach certain lessons in Mathematics and they ask students if the answer makes sense to the given problem and they look for other methods to solve it.

Table 8. Teachers' response to teaching methodological aspects.

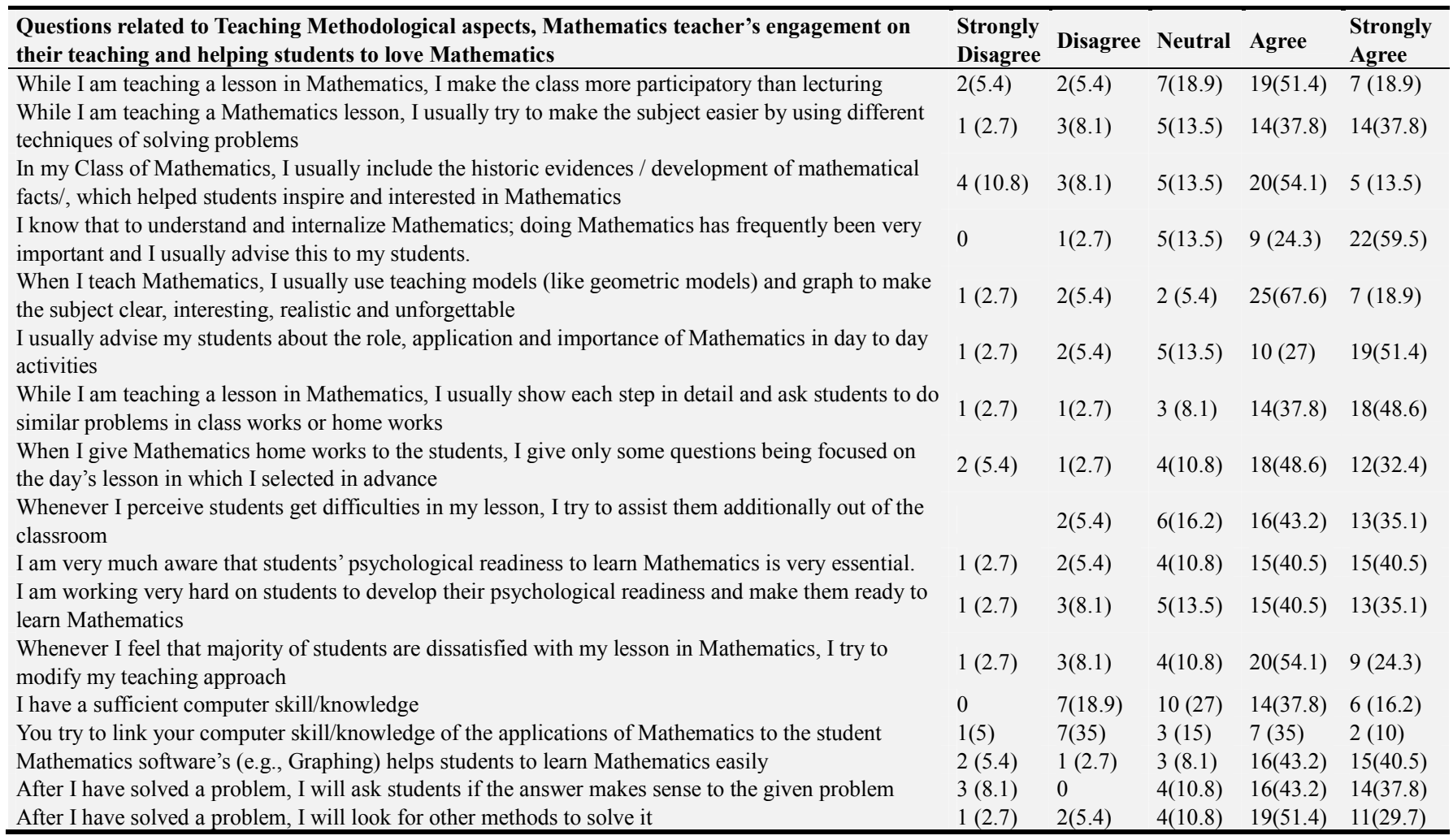

\subsubsection{Teachers Response on Attitudes of Students Toward Learning Mathematics}

To see the teachers' responses on students' attitudes towards learning Mathematics, different questions were raised for teachers. From these questions, it was found that most teachers disagreed with the idea that students show efforts to find out the reasons of their mistakes instead of simply accepting their mistakes while they solve mathematical problems. Additionally, the teachers disagreed 
with the idea that students struggle to go through the solution again and check if they made any mistake after they have solved a problem. They also disagreed that most students have confidence in solving Mathematics problems.

Most teachers agreed that students didn't figure out different ways to solve Mathematical problems as they didn't learn Mathematics from playing computer games and as they didn't think Mathematics is useful in solving real world problems. Most teachers agreed that students think the subject is boring.
Teachers also agreed that most students didn't understand the question itself before they give answers to the problem and they didn't try to understand the physical meaning of the mathematical solutions. In general, the teachers' response shows that most students had no good feelings about Mathematics and students usually think that studying Mathematics is useful only to pass from class to class since they think that they are not good enough in giving reasons in mathematical steps.

Table 9. Teachers' response on the attitudes of students toward learning Mathematics.

\begin{tabular}{|c|c|c|c|c|c|}
\hline Items related to the Attitudes toward student learning Mathematics & $\begin{array}{l}\text { Strongly } \\
\text { Disagree }\end{array}$ & Disagree & Neutral & Agree & $\begin{array}{l}\text { Strongly } \\
\text { Agree }\end{array}$ \\
\hline Most students try to find out the reason, if they know that they made a mistake in solving a problem & $8(21.6)$ & $9(24.3)$ & $6(16.2)$ & $13(35.1)$ & $1(2.7)$ \\
\hline Most students enjoy by doing Mathematics problem & $11(29.7)$ & $9(24.3)$ & $8(21.6)$ & $9(24.3)$ & 0 \\
\hline Most students have a chance to use computers in order to learn Mathematics & $10(27.0)$ & $14(37.8)$ & $9(24.3)$ & $1(2.7)$ & $3(8.1)$ \\
\hline Most students think that Mathematics is important & $2(5.4)$ & $8(21.6)$ & $9(24.3)$ & $12(32.4)$ & $6(16.2)$ \\
\hline After they have solved a problem, most students go through the solution again & $4(10.8)$ & $13(35.1)$ & $7(18.9)$ & $12(32.4)$ & $1(2.7)$ \\
\hline Most students have confidence in solving Mathematics problems & $7(18.9)$ & $12(32.4)$ & $10(27.0)$ & $6(16.2)$ & $2(5.4)$ \\
\hline Most students think that Mathematics is boring & $2(5.4)$ & $4(10.8)$ & $8(21.6)$ & $13(35.1)$ & $10(27.0)$ \\
\hline Students learn Mathematics from computer games & $6(16.2)$ & $13(35.1)$ & $14(37.8)$ & $2(5.4)$ & $2(5.4)$ \\
\hline Most students often figure out different ways to solve Mathematical problems & $4(10.8)$ & $14(37.8)$ & $13(35.1)$ & $5(13.5)$ & $1(2.7)$ \\
\hline Most students think Mathematics is useful in solving real world problems & $14(37.8)$ & $8(21.6)$ & $11(29.7)$ & $2(5.4)$ & $2(5.4)$ \\
\hline Most students can understand the question itself before they are going to answer the problem. & $4(10.8)$ & $15(40.5)$ & $10(27.0)$ & $8(21.6)$ & 0 \\
\hline Most students think Mathematics is easy & $14(37.8)$ & $12(32.4)$ & $9(24.3)$ & $1(2.7)$ & $1(2.7)$ \\
\hline Most students have good feelings about Mathematics & $7(18.9)$ & $16(43.2)$ & $6(16.2)$ & $4(4.8)$ & $4(4.8)$ \\
\hline Most students try to understand the physical meaning of the mathematical solutions. & $3(8.1)$ & $13(35.1)$ & $13(35.1)$ & $7(18.9)$ & $1(2.7)$ \\
\hline Most students think, studying Mathematics is useful only to pass from class to class. & $4(10.8)$ & $5(13.5)$ & $9(24.3)$ & $13(35.1)$ & $6(16.2)$ \\
\hline Most students think as they are not good in giving reasons for mathematical steps & $3(8.1)$ & $4(10.8)$ & $10(27.0)$ & $16(43.2)$ & $4(10.8)$ \\
\hline
\end{tabular}

\subsection{Multiple Comparisons Using ANOVA}

To compare students' mean scores with school types and father's occupation, ANOVA and multiple comparisons were made. Table 10 shows that students came from Comboni had significantly different mean score than that of the students in the two government schools, Tabor and Boricha, since the pvalue is less than $5 \%$ level of significance. The mean score for Comboni school (private) is much larger than the mean score of students came from the two government schools as shown in Table 10. Concerning to fathers' occupations, the result of Table 10 revealed that, students whose fathers were government employees had a different Mathematics score compared to students whose fathers were Merchant, NGO employees, and Farmers. Similarly, students whose families were farmers had significantly different Mathematics score when we compare them with students whose families were teachers.

Table 10. Multiple comparison between schools and father's occupations with students' grade 11.

\begin{tabular}{|c|c|c|c|c|c|c|}
\hline \multirow{2}{*}{ (I) Name of the School } & \multirow{2}{*}{ (J) Name of the School } & \multirow{2}{*}{ Mean Difference (I-J) } & \multirow{2}{*}{ Std. Error } & \multirow{2}{*}{ Sig. } & \multicolumn{2}{|c|}{ ANOVA Result } \\
\hline & & & & & F-Test & Sig. \\
\hline \multirow{2}{*}{ Tabor } & Boricha & 2.00959 & 2.060 & .330 & \multirow{4}{*}{5.26} & \multirow{4}{*}{0.006} \\
\hline & Comboni & $-6.60662^{*}$ & 2.237 & .003 & & \\
\hline \multirow{2}{*}{ Comboni } & Tabor & $6.60662^{*}$ & 2.237 & .003 & & \\
\hline & Boricha & $8.61621^{*}$ & 2.853 & .003 & & \\
\hline \multicolumn{7}{|l|}{ Occupation of students' father } \\
\hline \multirow{3}{*}{ Farmer } & Merchant & -1.95802 & 1.991 & .326 & \multirow{7}{*}{5.530} & \multirow{7}{*}{0.000} \\
\hline & NGO & -1.59263 & 1.991 & .424 & & \\
\hline & GEOFT & $-7.79385^{*}$ & 1.904 & .000 & & \\
\hline \multirow{4}{*}{$\begin{array}{l}\text { Government Employee Other } \\
\text { than teaching } \\
\text { (GEOFT) }\end{array}$} & Merchant & $5.83583^{*}$ & 1.854 & .002 & & \\
\hline & Farmer & $7.79385^{*}$ & 1.904 & .000 & & \\
\hline & Teacher & 1.66737 & 2.728 & .541 & & \\
\hline & NGO & $6.20121^{*}$ & 1.854 & .001 & & \\
\hline
\end{tabular}

In relation to students' interest to solve Mathematical problems together with their classmates and the average number of Mathematics class that the student attended per week out of five periods, students' achievement was compared at different category. Score of students who had no interest to solve Mathematical problems together with their classmates is significantly different from those students having some and/or great interest. That is, students who have 
a great interest to solve Mathematical problems with their classmates had the better Mathematics result than those students who had no interest at all.

Similarly, from Table 11, students who attended all 5 Mathematics classes per week had significantly different
Mathematics result from students' who attended 4 or less classes. The mean mathematics score of students who was attending all 5 classes/week is greater than the mean score of students who absent at least one class/week. The remaining two categories have no significance difference between each other.

Table 11. Comparison of Students Mathematics Score out of 100 in Grade 11 Based on their Interest to Solve Mathematics Problems with Colleagues and Attending Mathematics Classes.

\begin{tabular}{|c|c|c|c|c|c|c|}
\hline No. & Variable 1 & Variable 2 & Mean Difference (I-J) & Std. Error & Sig. & \\
\hline 1. & $\begin{array}{l}\text { (I) How is your interest to solve } \\
\text { Mathematical problems together } \\
\text { with your classmates }\end{array}$ & $\begin{array}{l}\text { (J) How is your interest to solve } \\
\text { Mathematical problems together } \\
\text { with your classmates }\end{array}$ & & & & \multirow{7}{*}{$\begin{array}{l}* \text { The mean difference } \\
\text { is significant at the } \\
0.05 \text { level with } \\
\mathrm{F}=18.273 \text { and } \mathrm{Sig} \text {. } \\
0.000\end{array}$} \\
\hline \multirow{12}{*}{2} & \multirow[b]{2}{*}{ No interest at all } & I have some interest & $-7.75659^{*}$ & 2.49499 & .002 & \\
\hline & & I have a great interest & $-13.44573^{*}$ & 2.52684 & .000 & \\
\hline & \multirow{2}{*}{ I have some interest } & No interest at all & $7.75659^{*}$ & 2.49499 & .002 & \\
\hline & & I have a great interest & $-5.68914^{*}$ & 1.33056 & .000 & \\
\hline & \multirow{2}{*}{ I have a great interest } & No interest at all & $13.44573^{*}$ & 2.52684 & .000 & \\
\hline & & I have some interest & $5.68914^{*}$ & 1.33056 & .000 & \\
\hline & $\begin{array}{l}\text { (I) To the average, how many } \\
\text { classes do you attend? }\end{array}$ & $\begin{array}{l}\text { (J) To the average, how many } \\
\text { classes do you attend? }\end{array}$ & & & & \multirow{6}{*}{$\begin{array}{l}\text { *. The mean difference } \\
\text { is significant at the } \\
0.05 \text { level with } \mathrm{F}= \\
6.729 \text { and Sig. } 0.001\end{array}$} \\
\hline & \multirow{2}{*}{ Attend all 5 classes } & Attend 3 or 4 classes & $5.59303^{*}$ & 1.78307 & .002 & \\
\hline & & Attend at most 2 classes & $6.92746^{*}$ & 3.15014 & .029 & \\
\hline & Attend 3 or 4 classes & Attend at most 2 classes & 1.33443 & 3.46522 & .700 & \\
\hline & \multirow{2}{*}{ Attend at most 2 classes } & Attend all 5 classes & $-6.92746^{*}$ & 3.15014 & .029 & \\
\hline & & Attend 3 or 4 classes & -1.33443 & 3.46522 & .700 & \\
\hline
\end{tabular}

\subsection{Independent T-Test on Sex, Attitude and Interest}

As indicated in the descriptive statistics in Table 12, the mean Mathematics score in grade 11 was 70.39 with a standard deviation of 12.75 for male students and 63.69 with a standard deviation of 11.17 for female students in the year 2007. Based on Table 12, there was a significant difference between male and female students' score as p-value is less than $5 \%$ level of significance.

Based on the result in Table 12, students who agreed with the idea that solving Mathematics word problems is difficulty were about $55 \%$ and those students who didn't agree with the idea were about $45 \%$. Moreover, the mean score of students who didn't agree with the difficulty of solving Mathematics word problems is 71.29 with a standard deviation of 12.69. However, the mean score of those students who agreed with the difficulty of solving Mathematics word problems is 63.73 with a standard deviation of 11.18 . This shows that the mean score of students who think solving Mathematics word problems is easy is greater than that of students who think solving Mathematics word problems is difficult. This variation in scores of students is confirmed by one sample ttest as it shows the significant difference between the two groups at the $5 \%$ level of significance.

Table 12 also shows that the general interest of students. Based on the result shown below, most $(66.33 \%)$ of the students were interested in Mathematics subject and the mean score of these students in grade 11 Mathematics subject was 69.15 with standard deviation 12.23. However, the mean score of students who were not interested in the subject was 63.16 with standard deviation 11.95 . This is supported by the independents sample t-test as p-value is smaller than the commonly used level of significance, which is $5 \%$. From this result, we can say that interest has significant impact on students score. That means, having a good interest in a given subject can increase students' performance.

Table 12. Independent sample t-test for students Mathematics score in grade $11^{\text {th }}$.

\begin{tabular}{|c|c|c|c|c|c|c|c|}
\hline No. & Variable & Category & N (\%) & Mean score (SD) & Mean Difference & t-calc. & Sig. \\
\hline 1 & Sex of respondents & $\begin{array}{l}\text { Male } \\
\text { Female }\end{array}$ & $\begin{array}{l}178(51.3 \%) \\
169(48.7 \%)\end{array}$ & $\begin{array}{l}70.39(12.75) \\
63.69(11.17)\end{array}$ & 6.7 & 5.192 & 0.000 \\
\hline 2 & $\begin{array}{l}\text { Solving Mathematics word } \\
\text { problems is difficult }\end{array}$ & $\begin{array}{l}\text { No } \\
\text { Yes }\end{array}$ & $\begin{array}{l}156(45 \%) \\
191(55 \%)\end{array}$ & $\begin{array}{l}71.29(12.69) \\
63.73(11.18)\end{array}$ & 7.56 & 5.896 & 0.000 \\
\hline 3 & $\begin{array}{l}\text { Overall interest of students to } \\
\text { Mathematics subject }\end{array}$ & $\begin{array}{l}\text { Not interested } \\
\text { Have interest }\end{array}$ & $\begin{array}{l}117(33.7 \%) \\
230(66.3)\end{array}$ & $\begin{array}{l}63.16 \\
69.15\end{array}$ & -5.99 & -4.343 & 0.000 \\
\hline
\end{tabular}

\subsection{Multiple Linear Regression Analysis}

Model summary is shown in Table 13. The value of adjusted R Square (0.508) indicates that $50.8 \%$ variation in students' performance is due to the independent variables included in the model. 
Table 13. Model summary.

\begin{tabular}{lllll}
\hline Model & \multirow{2}{*}{$\mathbf{R}$} & $\begin{array}{l}\mathbf{R} \\
\text { Square }\end{array}$ & $\begin{array}{l}\text { Adjusted R } \\
\text { Square }\end{array}$ & $\begin{array}{l}\text { Std. Error of the } \\
\text { Estimate }\end{array}$ \\
\hline 1 & $.727^{\mathrm{a}}$ & .529 & .508 & 8.742 \\
\hline
\end{tabular}

From Table 14, we can see the results of F-test, which was carried out to check the overall strength of the model. The pvalue is less than 0.05 level of significance. Thus, this model is better than the null model (model without any predictor). This leads us to conclude that at least one independent variable is included in the model, which has a significant effect on students' performance.

Table 14. ANOVA Table.

\begin{tabular}{llllll}
\hline Model & $\begin{array}{l}\text { Sum of } \\
\text { Squares }\end{array}$ & D.F. & $\begin{array}{l}\text { Mean } \\
\text { Square }\end{array}$ & F & Sig. \\
\hline Regression & 28341.739 & 15 & 1889.449 & 24.723 & $.000^{\text {b }}$ \\
Residual & 25220.016 & 330 & 76.424 & & \\
Total & 53561.754 & 345 & & & \\
\hline
\end{tabular}

a. Dependent Variable: Mathematics score in grade $11^{\text {th }}$ (Out of 100)

b. Predictors: (Constant), VPMC23_Excellent, Female, IIISMLI11_A, IIISMLI15_SA, VPMC3_C, GO, Study_15hr, VPMC23_weak, VPMC 13 _Some, IIISMLI15_A, VPMC23_V. Good, VPMC 3_A, VPMC3_B, VPMC23_good, VPMC13_Great

As displayed in Table 15, the relationship between the 15 independent variables and students' score in grade, 11th is expressed in the following regression model.

$$
\begin{aligned}
Y_{i}=43.28- & 3.49 X_{1}-4.97 X_{2}+3.46 X_{3}+2.77 X_{4} \\
& +5.78 X_{5}+7.20 X_{6}+12.09 X_{7}+18.89 X_{8} \\
& +4.43 X_{9}+5.86 X_{10}+6.59 X_{11}+6.56 X_{12} \\
& +7.51 X_{13}+8.82 X_{14}+11.00 X_{15}
\end{aligned}
$$

where,

$\mathrm{X}_{1}=$ Female $(\operatorname{Sex}=1$ for female respondents and $\operatorname{Sex}=0$ for male respondents)

$\mathrm{X}_{2}=$ IIISMLI11_A (If the student agrees that he/she is lazy in Mathematics and then he/she is not happy while attending Mathematics related subject $=1$, otherwise $=0$ )

$\mathrm{X}_{3}=\mathrm{GO}$ (If the student's father works in government organization $=1$ and otherwise $=0$ )

$\mathrm{X}_{4}=$ IIISMLI15_A (If the student agreed that Mathematics is an easy subject for him/her $=1$, otherwise $=0$ )

$\mathrm{X}_{5}=$ IIISMLI15_SA (If the student strongly agreed that Mathematics is an easy subject for him $/$ her $=1$, otherwise $=0$ )

$\mathrm{X}_{6}=$ VPMC3_C (If the student's Mathematics score is C in grade 10 coded as 1 , otherwise $=0$ )

$\mathrm{X}_{7}=$ VPMC3_B (If the student's Mathematics score is B in grade $10=1$, otherwise $=0$ )

$\mathrm{X}_{8}=$ VPMC3_A (If the student's Mathematics score is A in grade $10=1$, otherwise $=0$ )

$\mathrm{X}_{9}=$ VPMC13_Some (If a student has some interest to solve Mathematical problems together with his/her classmates $=1$, otherwise $=0$ )
$\mathrm{X}_{10}=$ VPMC13_Great (If student has great interest to solve Mathematical problems together with his/her class colleagues $=1$, otherwise $=0$ )

$\mathrm{X}_{11}=$ Study_15 (If the student spent 15 hours in studying Mathematics within a week $=1$, otherwise $=0$ )

$\mathrm{X}_{12}=$ VPMC23_weak (If a student has a weak communication with his/her Mathematics teacher $=1$, otherwise $=0$ )

$\mathrm{X}_{13}=$ VPMC23_Good (If a student has good communication with his/her teacher $=1$, otherwise $=0$ )

$\mathrm{X}_{14}=$ VPMC23_V. Good (If student has very good communication with his/her teacher $=1$, otherwise $=0$ )

$\mathrm{X}_{15}=$ VPMC23_Excellent (If student has excellent communication with his/her teacher $=1$, otherwise $=0$ )

Backward stepwise variable selection method was adopted to identify significant variables among the bunch of independent variables originally proposed by the researcher. In this study, only fifteen dummy variables were significant that determine the score of high school students in grade 11. All Variance Inflation Factor (VIF) values were small (smaller than 10), which indicated that there is no serious Multicollinearity problem.

At the 5 percent level of significance, having a father who works in a government organization, student's agreement with the idea that Mathematics is an easy subject, having $\mathrm{C}$, $\mathrm{B}$ or A grades in Mathematics in grade 10, having interest to solve Mathematical problems together with his/her classmates, spending 15 hours to study Mathematics within a week, and having communication with his/her Mathematics teacher has positive effect for students' Mathematics score in grade 11 . This result is in-line with the real situation. Parents who work in government organization helps their children to focus on their education than that of merchants may be is because they want their children to be employed. Students who believed that Mathematics is an easy subject usually has a better score than those students who think Mathematics is a difficult subject. A student who can score good result in national exam usually has better performance. For this particular study, students who scored $\mathrm{C}$ and above grades in Mathematics subject in Grade 10 National Exam had better Mathematics scores in grade 11 relative to students whose score is below C. Students who were interested to solve Mathematical problems together with their classmates have a better score than those students who were not interested. Students who spent enough time to study Mathematics within a week had a better score than those students who allocate very little or extended time. Moreover, students who communicate with their Mathematics teacher have better Mathematics score than those students who have poor communication. On the contrary, being lazy in Mathematics, and being not happy while attending Mathematics related subjects have a negative effect for students' Mathematics score in grade 11. In addition, males performed better in Mathematics than females.

The benchmarks for these dummy variables were male, not lazy, don't work in a government organization, Mathematics is not the easiest subject, Mathematics' score in grade 10 is 
below $\mathrm{C}$, has no any interest to solve Mathematics, spending more than 15 or less hours to study Mathematics within a week, and poor communication with Mathematics teacher. All comparisons were made in relation to these categories. The average score of students in grade 11, in this benchmark category was about 43.28. Compared with this, the average score of female students in grade 11 was lower by 3.49 (i.e. 43.28-3.49). Similarly; for those students who agreed that he/she is lazy in Mathematics and then he/she is not happy while attending Mathematics related subjects, their average score in grade 11 was lower by 4.97 for actual average score of 38.31. On the other hand; for those students whose father works in government organization, their average score in grade 11 was higher by 3.46 for actual average score of 46.74. In the same manner; for those students who agreed that Mathematics is an easy subject for them, their average score in grade 11 was higher by 2.77 for actual average score of 40.51. Likewise; for those students who strongly agreed that Mathematics is an easy subject for them, their average score in grade 11 was higher by 5.78 for actual average score of 49.06. For those students whose Mathematics' grade is $\mathrm{C}$ in grade 10 , their average score in grade 11 was higher by 7.20 for actual average score of 50.48. For those students whose Mathematics' grade is B in grade 10, their average score in grade 11 was higher by 12.09 for actual average score of 55.37. For those students whose Mathematics' grade is $\mathrm{A}$ in grade 10, their average score in grade 11 was higher by 18.89 for actual average score of 62.17 .

Regarding to interest; for those students who has some interest to solve Mathematical problems together with his/her classmates, their average score in grade 11 was higher by 4.43 for actual average score of 47.71 . For those students who have great interest to solve Mathematical problems together with his/her classmates, their average score in grade 11 was higher by 5.86 for actual average score of 49.14 . Considering the study time; for those students who spent 15 hours in studying Mathematics within a week, their average score in grade 11 was higher by 6.59 for actual average score of 49.87.

Concerning students' communication with Mathematics teacher; for those students who has weak communication with his/her Mathematics teacher, their average score in grade 11 was higher by 6.56 for actual average score of 49.84. For those students who had good communication with his/her Mathematics teacher, their average score in grade 11 was higher by 7.51 for actual average score of 50.79. For those students who had very good communication with his/her Mathematics teacher, their average score in grade 11 was higher by 8.82 for actual average score of 52.10 . For those students who had excellent communication with his/her Mathematics teacher, their average score in grade 11 was higher by 11 for actual average score of 54.28.

Table 15. Parameter estimation.

\begin{tabular}{|c|c|c|c|c|c|c|c|c|c|}
\hline \multirow[t]{2}{*}{ Model } & \multicolumn{2}{|c|}{$\begin{array}{l}\text { Unstandardized } \\
\text { Coefficients }\end{array}$} & \multirow{2}{*}{$\begin{array}{l}\text { Standardized } \\
\text { Coefficients } \\
\text { Beta }\end{array}$} & \multirow[t]{2}{*}{$\mathbf{T}$} & \multirow[t]{2}{*}{ Sig. } & \multicolumn{2}{|c|}{ 95\% Confidence Interval for B } & \multicolumn{2}{|c|}{ Collinearity Statistics } \\
\hline & B & Std. Error & & & & Lower Bound & Upper Bound & Tolerance & VIF \\
\hline (Constant) & 43.281 & 2.860 & & 15.134 & .000 & 37.655 & 48.906 & & \\
\hline Female & -3.485 & .980 & -.140 & -3.555 & .000 & -5.414 & -1.557 & .920 & 1.087 \\
\hline IIISMLI11_A & -4.970 & 1.490 & -.129 & -3.335 & .001 & -7.902 & -2.039 & .952 & 1.050 \\
\hline GO - & 3.459 & 1.091 & .124 & 3.169 & .002 & 1.312 & 5.606 & .931 & 1.074 \\
\hline IIISMLI15_A & 2.770 & 1.194 & .100 & 2.321 & .021 & .422 & 5.117 & .769 & 1.301 \\
\hline VPMC3_C & 7.202 & 1.910 & .270 & 3.771 & .000 & 3.446 & 10.959 & .279 & 3.580 \\
\hline VPMC3_B & 12.092 & 1.903 & .471 & 6.356 & .000 & 8.350 & 15.835 & .259 & 3.856 \\
\hline VPMC3_A & 18.894 & 2.064 & .635 & 9.155 & .000 & 14.834 & 22.954 & .297 & 3.367 \\
\hline VPMC $1 \overline{3}$ Some & 4.434 & 1.948 & .178 & 2.276 & .023 & .602 & 8.266 & .233 & 4.294 \\
\hline VPMC13_Great & 5.859 & 2.021 & .233 & 2.900 & .004 & 1.884 & 9.834 & .222 & 4.509 \\
\hline Study_15hr & 6.592 & 1.841 & .144 & 3.582 & .000 & 2.971 & 10.213 & .877 & 1.141 \\
\hline VPMC 23 _weak & 6.564 & 1.974 & .235 & 3.325 & .001 & 2.680 & 10.447 & .286 & 3.491 \\
\hline VPMC23_good & 7.507 & 1.936 & .295 & 3.877 & .000 & 3.698 & 11.316 & .246 & 4.059 \\
\hline VPMC23_Excellent & 11.002 & 2.330 & .297 & 4.722 & .000 & 6.419 & 15.586 & .360 & 2.781 \\
\hline
\end{tabular}

\section{Conclusion}

The purpose of this study was to assess the students' background, performance, interest, and attitude towards Mathematics; and their teachers' response on teaching methodologies, physical facilities, and students attitude towards learning Mathematics.

From the empirical results, it can be concluded that students who come from Comboni school (private school) have better Mathematics performance than those students who came from the two government schools (Tabor and
Boricha). Students whose fathers were government employees (other than teaching) had a better Mathematics score compared to students whose fathers were Merchant, NGO employees, and Farmers. Score of students who had no interest to solve Mathematical problems together with their classmates was significantly less compared to students that had some and/or great interest. Similarly, students who attended all Mathematics classes in the week had significantly higher scores in Mathematics than those who attended fewer classes.

From the result, it can also be concluded that there was a significant Pertaining to gender difference between male and 
female students' score where males had better scores than female in Mathematics. The mean score of students who didn't agree with the difficulty of solving Mathematics word problems was significantly higher than those students' scores who had some difficulties. Generally, the mean Mathematics score in grade 11 was significantly higher for those students having an interest in the subject. Among the initially proposed factors; sex of students, students' laziness to attend Mathematics related courses, and students believe that Mathematics is not an easy subject had a significant negative effect on students' performance in the grade 11 Mathematics course. On the contrary, scoring better grade $(\mathrm{C}, \mathrm{B}$, and $\mathrm{A})$ in grade 10 national exam, student interest to solve Mathematical problems with their classmates, the time that the student spends per week to study Mathematics, and having better communication with Mathematics teacher had a significant positive effect on students' performance in the grade 11 Mathematics course.

\section{Implications}

Based on the findings of this study, authors forward the following recommendations:

1. Students should take time to do Mathematics problems with their classmates in order to understand Mathematics in a better way.

2. Students should spend relatively longer time to study Mathematics in order to get a better grade.

3. Students should communicate with Mathematics teacher in order to improve their Mathematics performance.

4. Schools should prepare tutorial programs for female students.

5. The government should give special attention for the Mathematics subject and Mathematics graduate in order to improve students' performance in Mathematics and to apply Mathematics in science and technology in a better way.

6. Further studies should be conducted to identify other correlates of Mathematics performance.

\section{References}

[1] Cuoco, A., (1995). Some Worries about Mathematics Education, Math. Teacher, 88, 186-187.

[2] Fennema, E., \& Sherman, J. A. (1976). Fennema-Sherman Mathematics Attitudes Scales: Instruments Designed to Measure Attitudes toward the Learning of Mathematics by Females and Males. Journal for Research in Mathematics
Education, 7 (5), 324326. doi: 10.2307/748467.

[3] Aiken, L. R. (1970). Attitudes towards Mathematics. Review of Educational Research, no.40.

[4] Akinsola, M. K., \& Olowojaiye, F. B. (2008). Teacher instructional methods and student attitudes towards mathematics. International Electronic Journal of Mathematics Education, 3 (1), 60-73.

[5] Hart, L. E. (1989). Describing the affective domain. Saying what we mean. In D. B. McLeod \& V. M. Adams (Eds.), Affect and mathematical problem solving: A new perspective (pp. 37-48). New York: Springer.

[6] Hiebert, J., \& Carpenter, T. P. (1992). Learning and teaching with understanding. In D. A. Grouws (Ed.), Handbook of research on mathematics teaching and learning (pp. 65-97). New York: Macmillan.

[7] Johnson, M. L. (1984). Blacks in mathematics: A status report. Journal for Research in Mathematics Education, 15, 145-153.

[8] Kenny, J. and Russell, A. (2014). Student's Attitude towards Mathematics at the University of Evora, Portugal, Proceedings of EDULEARN 14 Conference 7th -9th July 2014, Barcelona, Spain, ISBN: 978-84-617-0557-3.

[9] Ma, X., \& Kishor, N. (1997). Assessing the relationship between attitude toward mathematics and achievement in mathematics: a meta-analysis. Journal for Research in Mathematics Education, 28 (1), 26-47.

[10] Mandler, G. (1989). Affect and Learning: Causes and Consequences of Emotional Interactions. In D. B. McLeod and V. M. Adams (Eds), Affect and Mathematical ProblemSolving: A New Perspective (pp. 3-19). New York: SpringerVerlag.

[11] McLeod, D. B. (1994). Research on affect and mathematics learning. Journal for Research in Mathematics Education, 25, 637-647.

[12] Mensah, J. K. (2013). Student Attitude towards Mathematics and Performance: Does the Teacher Attitude Matter? Journal of Education and Practice, ISSN 2222-1735 (Paper) ISSN 2222-288X (Online), Vol. 4, No. 3, 2013.

[13] Nicolaidou, M. and Philippou, G. (2001). Attitudes Towards Mathematics, Self-Efficacy and Achievement in ProblemSolving, European Research in Mathematics Education III.

[14] Odhiambo, E. O. and Standslause (2013). Teachers and Students Attitude towards Mathematics in Secondary Schools in Siaya County, Kenya, Asian Journal of Management Sciences and Education, ISSN: 2186-845X, ISSN: 2186-8441 Print, Vol. 2, No. 3, July 2013.

[15] Zan, R. and Martino, P. D. (2007). Attitudes toward Mathematics: Overcoming positive/negative dichotomy. The Montana Mathematics Enthusiasts Monograph, 3, 157-168. 